\title{
Tribute to the dissected corpses: the anatomic symbol - a review of the anatomic symbol
}

\author{
Fontes, E. B., Precht, B. L. C., Babinski, M. A. and Cisne, R.* \\ Department of Morphology, Biomedical Center, Universidade Federal Fluminense - UFF, \\ Rua Prof. Ernani Melo 101, São Domingos, CEP 24290-130, Niterói, RJ, Brazil \\ *E-mail: rafael.cisne@gmail.com
}

\begin{abstract}
Introduction: The anatomical science has many stages in its history and different origins that makes it hard to define a universal symbol among anatomists. Discussion: Many anatomical schools have adopted the Leonardo Da Vinci's drawing called "Vitruvian Man" as the symbol of the modern anatomy. However, this draw brings a symmetric view of the body within the mathematical proportions of the segments. Nevertheless, the anatomical study element is not symmetric and has a single architecture with beautiful harmony among its components. This element, the cadaver is the biggest treasure of the anatomical science and depository of all truths. Conclusion: This current work represents a tribute to the dissected cadaver, concerning it immeasurable value to the anatomist and the traditional use of it in anatomy department pointing to the new perspectives for academic and artistic conceptions of the human body.
\end{abstract}

Keywords: cadaver, symbol, anatomy, dissection, plastination.

\section{Introduction}

The knowledge of the body's architecture is requested for several activities, as artistic representations, as well is primordial to medical practice. The traditional method to develop the knowledge on this science came from dissection procedures.

In ancient times, anatomy knowledge was the only request for medical practice, what reveals its importance in this field (LIARD and LATARJET, 1996). The sentence "There is no medicine without anatomy!" ("Nulla medicina sine anatomia!") lives in morphological science's heart (DI DIO, 1999). The traditional source of this knowledge for the anatomist is the cadaver. The cadaver is then proclaimed by all the engaged in the knowledge of the divine architecture as the most valuable matter to investigation which lies in an abode of triumph where the dead teaches the living ones ("Hic mortui vivas docent", "Hic locus est ubi mors gaudet succurrere vitae") (TUBBS and LOUKAS, 2009).

This paradigm suggests the intellectual element that in the death's silence, the anatomist finds the truth ("In mortis silentio veritatem inquirens").

\section{Body Representations}

A plenty number of artists were engaged in graphically convert their knowledge on human anatomy into paintings, mainly during Modern Ages. The difference between their many artistic styles and influences is notable and exceptional (KEMP, 2010). Perhaps, the most recognized artistic pieces are those from the Renaissance time, due to the incredible anatomic and artistic development of this period (EKNOYAN, 2000; AFEK, FRIEDMAN, KUGEL et al., 2009; BAY and BAY, 2010). However, other different pre-Renaissance and post-Renaissance representations have their cultural, aesthetic and pedagogical importance (KEMP, 2010; PETAROS, CULINA, SURAN et al. 2013). If we extend the observation to the anatomy development in non-occidentals societies, the distinction between it aspects are intensified, thanks to the influence of oriental traditional medical sciences to anatomic scientific, as well as artistic productions of these cultures. A great example is the development of anatomy in Japan, which is a result of both occidental and oriental presences (TUBBS, LOUKAS, KATO et al. 2009).

Then, the Renaissance seems to be the period with the highest number of anatomical artistic. Several authors have demonstrated virtuous performances using the anatomical knowledge, as Da Vinci, who was a famous artist, inventor, scientist and anatomist. His extraordinary intelligence, creativity, associated with a great power of invention and curiosity, gave him the fame of "Renaissance Genius". The latter half of his life was devoted to a very successful, large and precise anatomic study (BAY and BAY, 2010). His drawing called Vitruvian Man” was recognized as reference by representing the ideology of equilibrium and appreciation of the man, humanity, rationalism and science. Furthermore, it demonstrates a perspective of human body proportions, with a naked man in two superimposed positions with the limbs contained within a circle and a square and in many ways resembles the modern anatomical position. This amazing representation is based on the roman architect Marcus Vitruvius Pollio's treatise, “On Architecture" (VITRUVIUS, 1914; LE FLOCH-PRIGENT, 2008).

The image is iconic, and has been frequently presented in advertisements and logos, related or not to medicine (LE FLOCH-PRIGENT, 2008; BAY and BAY, 2010). The figure of the "Vitruvian Man" symbolizes a basic symmetry of the human body and mathematical proportions of its segments (VITRUVIUS, 1914). Although the element of this anatomic study shows an apparent symmetry, the historical study of the body shows a different perspective (CRIVELLATO 
and RIBATTI, 2008). Therefore, the "Vitruvian Man" is established as a current conventional symbol, which presents itself as a synthesis of that artistic moment, but not the whole contextualized anatomy.

\section{Who Were They?}

Despite the intermittent use of cadavers during ancient times, the human dissection was regularly established in Europe after the publishing of Italian and French anatomy texts from authors such as Vesalius and Mondino dei Luzzi after the 14th and 15th centuries (MITCHELL, BOSTON, CHAMBERLAIN et al., 2011; OLRY, 1997; VESALIUS, 1543). These texts emphasized the importance of dissection and, then, anatomists received authorization to dissect criminals after their deaths from hanging (PERSUAD, 1997). However, the number of bodies available did not reach the growing demand of corpses to medical and surgical training (MITCHELL, BOSTON, CHAMBERLAIN et al., 2011).

Due to this difficulty, an efficient alternative was developed. Despite it illegality, cadavers exhumation became a profitable activity with an avid consumer market (SHULTZ, 1992). Body snatching became a problem of public order and security because of many episodes of grave robbing and even murders (OLRY, 1999).

As response to this outrageous practice, many anatomical acts were created with an intention to regularize the use of cadavers on medical teaching over America and Europe. One of the great examples of those legal instruments was the Anatomy Act of 1832 that provided access to dissect corpses of those who died in workhouses or prisons in the United Kingdom (ENGLAND, 1832). However, historical evidence demonstrates that exploration of poverty was the basis of this new paradigm (HALPERIN, 2007). In a general way, the social vulnerability of some social groups was explored by the use of slaves, african americans, immigrants, prisoners executed by authoritarian regimes and mentally ill patients as subjects to dissection after their deaths (JONES and WHITAKER, 2012; HILDEBRANDT, 2009).

Nowadays, unclaimed bodies are still used for dissection and anatomy teaching over the world, but the frequency of this practice is declining. An interesting parallel can be drawn since unclaimed bodies represent a minority of the bodies in Canadian and United States schools (DASGUPTA, 2004), but are still widely used in Africa, Bangladesh, India and Brazil, for example (GANGATA, NTABA, AKOL et al., 2010; CHAKRABORTY, KHAN, ISLAM et al., 2010; AJITA and SINGH, 2007; MELO and PINHEIRO, 2010).

As a resolution to the ethical issues involved on the use of unclaimed bodies, new body donation programs are the modern strategy to supply the demand of corpses to dissection and, more recently, to public display (JONES and WHITAKER, 2012). This new model faces its current limitations on new ethical constraints and cultural influences, as will be discussed.

\section{Cadaver as Symbol}

Most of human activities have symbols to represent them and its processes. These symbols turn up as the objects or figures that provide us a major understanding about the reality that surrounds us (PRATES, 2005). The symbols are divided in conventional and universal. The conventional has the simple function to introduce the represented information, while the universal has a deeper meaning, drawing our attention to the idiosyncrasies in the theme involved (NAGER, 1993).

The anatomic science comprehends many stages in its history and a vast variety of references. In this field, the situation remains unchanged, since the symbolism is not precise.

Due to the development of anatomy on different historical periods and locals, the spontaneous emergence of just one symbol, which comprehends all the meanings of anatomy to each society, was impossible. Instead, each artistic expression that intended an anatomic representation exposes morals, religious, cultural and social conceptions, related to the epoch when they were idealized.

Therefore, to preserve its importance and to transmit to old and new enthusiasts of anatomy, the cadaver is now proposed as an universal symbol used to represent the unmatched complexity of anatomic structures disposition, relations, variations and individualities, and represents a reference to unify anatomic symbolism on different cultures.

\section{History of Dissection Over the World}

Along the centuries, the study of corpse, by dissection or prosection, became the most important and traditional source of knowledge for the morphological sciences in many medical traditions all over the world (KORF, WICHT, SNIPES et al., 2008). For occidental tradition, dissection started in ancient Greece, culminating with the Galen's Treaty of Anatomy based on comparative anatomy. During the Middle Ages, dissections were prohibited (GREGORY and COLE, 2002) and then were resumed in French and Italian universities during the 14th and 15th centuries (ELIZONDO-OMANA, GUZMÁN-LÓPEZ and GARCÍA-RODRÍGUEZ 2005). In the United Kingdom, the arrival of Italian and French printed anatomical texts on the 17th century encouraged many anatomists to human dissection, such as the famous William Harvey (Substituir por MITCHELL, BOSTON, CHAMBERLAIN et al., 2011; PAYNE, 2002).

European anatomists, such Andreas Vesalius with his revolutionary De humani corporis fabrica, are more celebrated between the scientific community, but they are not the only ones to search in cadaveric specimens the answers to their thirst of knowledge. The Japanese anatomist Toyo Yamawaki participated in dissections as early as 1754. In 1770, Shinnin Kawaguchi completed the fifth dissection recorded in Japan (TUBBS, LOUKAS, KATO et al., 2009). Susruta Samhita in the 6th century $\mathrm{BC}$ was a proponent of human dissection in India (LOUKAS, LANTERI, FERRAUIOLA et al., 2010). Evidence indicates the use of bodies of animals and condemned criminals to dissection and description of many systems centuries BC by the Persian anatomists (SHOJA and TUBBS, 2007). In Alexandria, Herophilus and Erasistratus began the practice of human dissection (250 BC) (LOUKAS, HANNA, ALSAIEGH et al., 2011).

The historic importance of these and many others anatomists is not contemplated by the current anatomic symbol since their scientific and artistic cultures are different from the occidental. However, those different perspectives share a unique common aspect, dissection.

The experience of dissection enabled all the anatomists to perceive the human body as an imperfect and asymmetric construction since each corpse has a unique composition, the 
result of environmental, genetic and pathological influences (WOLPERT, 2005; CRIVELLATO and RIBATTI, 2008; ZAIDI, 2011).

\section{Cadaver as Teacher}

The knowledge of anatomic science is essential to the medical education. This knowledge is obtained mainly by dissection and prosection (AJITA and SINGH, 2007). It is natural for some anatomists to keep anatomy and dissection as indistinguishable matters due to cultural tradition of dissections along anatomy history and even due to the origin of the word "anatomy" from the Greek "anatome", a cutting apart (MOORE, 1998). Dissection is a unanimous tradition of all anatomical cultures. Recently, a study showed that the majority of anatomy courses still use dissection as educational tool in United States (DRAKE, MCBRIDE, LACHMAN et al., 2009). In Russia, the undergraduate teaching is mainly based on dissections, prosection in association with the study of operative surgery topics (KAGAN, 2002). A study carried out in the United Kingdom reported that dissection was still taught in $76 \%$ of the anatomy departments assessed and 25\% of these used dissection exclusively (HEYLINGS, 2002).

Even so, there is an intense academic debate around substituting dissections by anatomical plastic models and digital resources (MCLACHLAN, BLIGH, BRADLEY et al., 2004). Despite the good intention when introducing problem-based learning curriculum, this kind of statement is dangerous since dissection occupies a complex role in anatomical education.

Although the contact with the dead body is a trigger to problematic psychological reactions such as anxiety (ARRAEZAYBAR, CASADO-MORALES, and CASTANO-COLLADO, 2004), the dissected cadaver has a crucial role on medical professional construction since it represents emotional challenges that require empathy, respect and self-reflection from the student (WARNER and RIZZOLO, 2006). A qualitative study assessed perceptions of dissection by students and revealed that characteristics of dissection such as working with small groups, close supervision and hands-on learning were appreciated by that sample (LEMPP, 2005). The experiences inside the dissection laboratories prepare the students to deal with their professional's problems collectively, using ethic, judgment skills and reason (SLOTNICK and HILTON, 2006). From a perspective of gross anatomy, the use of bodies enables the construction of multidimensional mental images that are useful on daily medical practice (MARKS JUNIOR, 2000) and introduces the students to the anatomical variability and pathology that they will face during their careers (GRANGER, 2004). Dissection is also an opportunity for the student to improve basic surgical skills and to practice procedures techniques in a stress-free environment (PARKER, 2002). Students found the involvement with cadavers directly connected to the medical formation process (NETTERSTRØM and KAYSER, 2008).

Nowadays, the acquisition of cadavers is a huge difficulty for many morphology institutes, departments and scientists (SEHIRLI, SAKA and SARIKAYA 2004). Nevertheless, some countries with efficient donation programs have an adequate number of bodies to dissection (WIJBENGA et al., 2010). One of current challenges to dissection is to increase the number of bodies obtained by anatomy departments and keep dissection alive for students. Religious beliefs and cultural influences restrain the number of bodies donated (SEHIRLI,
SAKA and SARIKAYA, 2004; MCHANWELL, BRENNER, CHIRCULESCU et al., 2008). The wish to contribute to science, to contribute to education and to help others seems to be major motivations to donation (BOLT et al., 2010).

As didactic complements, new alternative pedagogical resources like plastic models and multimedia features were developed for anatomy teaching. Although it shows great results, the cadaver study remains as the traditional source to psychosocial and emotional development of the students allied with anatomical understanding of the three-dimensional structures and it relations, contemplating the natural texture, variance and pathology (ARRAEZ-AYBAR, CASTANOCOLLADO and CASADO-MORALES, 2008; SUGAND, ABRAHAMS and KHURANA 2010). It is necessary to overcome the lack of cadavers and, at the same time, to maintain a harmonic integration with the new educational methodologies (ELIZONDO-OMANA, GUZMÁN-LÓPEZ and GARCÍA-RODRÍGUEZ 2005).

Then, a simple question became unavoidable: How to establish this harmony between the traditional methods and the new technologies, bringing again the cadaver to a highlighted and aesthetic position for anatomy teaching? Probably, the answer to that question lies not only inside the traditional dissection laboratories.

Body bequest programs are great examples of established strategies that increase the acquirance of new cadavers (CORNWALL and STRINGER, 2009; AKINOLA, 2011). Another strategy is the use of plastinated specimens for teaching. As we can see, for modern anatomy symbolism, plastination has a vaster meaning than just an educational tool.

\section{The Plastinated Cadaver - A New Artistic Perspective}

Today, the plastination phenomenon represents an anatomic revolution in all aspects. The technique developed by Gunther von Hagens at the Heidelberg University enabled the conception of new methodologies of anatomy teaching, scientific research and was even capable to influence forever the way that body is observed (JONES, 2002).

This technique arose as a biologic tissue impregnation method under vacuum with resins and elastomers, replacing tissues components by polymers (VON HAGENS, 1979).

Plastination seems to be consolidated as an important instrument for teaching anatomy because of the long-term tissue preservation characteristic (RIEDERER, 2013). Plastinated specimens are now included as a great tool to the modern multi-modal anatomical teaching programs (REIDENBERG and LAITMAN, 2002). These specimens overcome the conventional plastic models because they represent anatomical variations, have great durability, are easy to use and also avoid the exposure to toxic substances (O'SULLIVAN and MITCHELL, 1995; LATORRE, GARCÍA-SANZ, MORENO et al., 2007). The possibility to correlate cross-sections to radiologic images adds even more relevance to the use of plastination for teaching applied and gross anatomy (JONES and WHITAKER, 2009).

The role of plastination on scientific research is still incipient, but already prosperous (JONES and WHITAKER, 2009). In the literature, many references are examples to the use of plastination to macroscopic (SORA and GENSER-STROBL, 2005; FRITSCH, PINGGERA, LIENEMANN et al., 2006) and microscopic studies (NASH, PHILLIPS, NICHOLSON et al., 
2004), including the possibility to use new methodologies of three-dimensional analyses of tissues (MARKS, CHANEY and BOPPART, 2008). New technologies enable digital reconstruction of segments, using anatomic plastinated cuts (SORA, GENSER-STROBL, RADU et al., 2007). The current moment of plastination is propitious to innovation and creation of new perspectives to the use of plastinated tissues on research since limitations of this technique are not totally explored.

Perhaps, the most revolutionary aspect of plastination is not related to teaching, research or even to morphology institutes and laboratories. Gunther von Hagens proposed a different experience to modern anatomy: the exposure of plastinated specimens to general public as art. The exposition BODY WORLDS is the presentation of a natural art, the " $[\ldots]$ aesthetic and instructive presentation of the body's interior" (VON HAGENS and WHALLEY, 2009, p. 11-14). During the centuries, anatomy was established as a science and lost the artistic dimension to the anatomists. Finally, it was reduced to medical education and necropsy for pathology studies. Von Hagen's Anatomy Art intends to rescue the aesthetic value, emotional fascination and humanistic interest in dead bodies, breaking with taboos and bringing to public the discussion about death. On the exposition, the specimens are positioned and technically prepared with the thoroughness that reveals Von Hagens as a special artist of the living anatomy. "Von Hagen values the uniqueness of each individual specimen, arguing that each plastinate reveals the particular vicissitudes and anomalies of real individuals" (MOORE and BROWN, 2004 , p. 14-20). As an artistic proposal, BODY WORLDS is well succeeded since it promotes a social, ethic and cultural discussion about death, body functions, health, pathology and anatomy. A survey assessed public reaction to the exhibitions. The specimens incited fascination to $94.7 \%$ of the public, $49.8 \%$ felt disturbed, $81.4 \%$ wanted to know more about their own body and $86.1 \%$ stated that they are better informed about their body anatomy and functioning (LEIBERICH, LOEW, TRITT et al., 2006). Another study shows that 53\% decided to pay more attention to their health and $69 \%$ perceived the vulnerability of the body (LANTERMANN, 2001). These statistics are the statement of plastination as a revolutionary and transforming process that put the human body again as a symbol in a center position of contemplation and reflection about our own anatomy and physiology. The probable result of this process is the appreciation and recognition of the cadaver as a symbol to society.

\section{Conclusion}

Despite the changes that are occurring in anatomy, we cannot forget the value of cadavers along history. The use of cadavers should be encouraged and stimulated not only for formal education and research, but also to promote a debate among society. The probable best solution to scarce supply of cadavers are body bequest programs. An alternative to this problem is the use of plastinated specimens since the technique has the advantage of efficient long-term preservation of tissues. To this end, the corpse is essential to medical learning and it is primordial that anatomists keep in mind that the cadaver is the biggest treasure of the anatomical science and depository of all anatomical truths.

\section{Conflict of interests}

None.

\section{References}

AFEK, A., FRIEDMAN, T., KUGEL, C., BARSHACK, I. and LURIE, DJ. Dr. Tulp's anatomy lesson by rembrandt: the third day hypothesis. The Israel Medical Association Journal: IMAJ, 2009, vol. 11, n. 7, p. 389-392.

AJITA, R. and SINGH, I. Body donation and its relevance in anatomy learning - a review. Journal of the Anatomical Society of India, 2007, vol. 56, n. 1, p. 11.

AKINOLA, OB. Formal body bequest program in Nigerian medical schools: when do we start? Anatomical Sciences Education, 2011, vol. 4, n. 4, p. 239-242.

ARRAEZ-AYBAR, LA., CASADO-MORALES, MI. and CASTANOCOLLADO, G. Anxiety and dissection of the human cadaver: an unsolvable relationship? Anatomical record. Part B, New Anatomist, 2004, vol. 279, n. 1, p. 16-23.

ARRAEZ-AYBAR, LA., CASTANO-COLLADO, G. and CASADOMORALES, MI. Dissection as a modulator of emotional attitudes and reactions of future health professionals. Medical Education, 2008, vol. 42 , n. 6 , p. $563-571$.

BAY, NSY. and BAY, BH. Da Vinci's anatomy. Journal of Morphological Sciences, 2010, vol. 27, n. 1, p. 11-13.

BOLT, S., VENBRUX, E., EISINGA, R., KUKS, JB., VEENING, JG. and GERRITS, PO. Motivation for body donation to science: more than an altruistic act. Annals of anatomy = Anatomischer Anzeiger: Official Organ of the Anatomische Gesellschaft, 2010, vol. 192, n. 2 , p. $70-74$.

CHAKRABORTY, S., KHAN, H., ISLAM, S. and YOUSUF, BMA. Body donation and its significance in anatomy learning in Bangladesh: a review. Bangladesh Journal of Anatomy, 2010, vol. 8, p. 85-88.

CORNWALL, J. and STRINGER, MD. The wider importance of cadavers: educational and research diversity from a body bequest program. Anatomical Sciences Education, 2009, vol. 2, n. 5, p. 234-237.

CRIVELLATO, E. and RIBATTI, D. Body symmetry and asymmetry in early Greek anatomical reasoning. Clinical Anatomy, 2008, vol. 21, n. 4 , p. 279-282.

DASGUPTA, N. Unclaimed bodies at the anatomy table. Jama, 2004, vol. 291, n. 1, p. 122.

DI DIO, LJ. The importance of anatomy. Annales d'Anatomie Pathologique, 1999, vol. 181, n. 5, p. 455-465.

DRAKE, RL., MCBRIDE, JM., LACHMAN, N. and PAWLINA, W. Medical education in the anatomical sciences: the winds of change continue to blow. Anatomical Sciences Education, 2009, vol. 2, n. 6, p. 253-259.

EKNOYAN, G. Michelangelo: art, anatomy, and the kidney. Kidney International, 2000, vol. 57, n. 3, p. 1190-1201.

ELIZONDO-OMANA, RE., GUZMÁN-LÓPEZ, S. and GARCÍARODRÍGUEZ, ML. Dissection as a teaching tool: past, present, and future. Anatomical Record. Part B, New Anatomist, 2005, vol. 285, n. 1, p. 11-15.

ENGLAND. An Act for regulating Schools of Anatomy. Anno Secundo \& Tertio. Gulielmi IV. Regis. Cap LXXV. London, 1832.

FRITSCH, H., PINGGERA, GM., LIENEMANN, A., MITTERBERGER, M., BARTSCH, G. and STRASSER, H. What are the supportive structures of the female urethra? Neurourol Urodyn, 2006, vol. 25, n. 2 , p. 128-134.

GANGATA, H., NTABA, P., AKOL, P. and LOUW, G. The reliance on unclaimed cadavers for anatomical teaching by medical schools in Africa. Anatomical Sciences Education, 2010, vol. 3, n. 4, p. 174-183. 
GRANGER, NA. Dissection laboratory is vital to medical gross anatomy education. Anatomical Record. Part B, New Anatomist, 2004, vol. 281, n. 1, p. 6-8.

GREGORY, SR. and COLE, TR. The changing role of dissection in medical education. Jama, 2002, vol. 287, n. 9, p. 1180-1181.

HALPERIN, EC. The poor, the black, and the marginalized as the source of cadavers in United States anatomical education. Clinical Anatomy, 2007, vol. 20, n. 5, p. 489-495.

HEYLINGS, DJ. Anatomy 1999-2000: the curriculum, who teaches it and how? Medical Education, 2002, vol. 36, n. 8, p. 702-710.

HILDEBRANDT, S. Anatomy in the third reich: an outline, part 2. Bodies for anatomy and related medical disciplines. Clinical Anatomy, 2009, vol. 22, n. 8, p. 894-905.

JONES, DG. and WHITAKER, MI. Anatomy's use of unclaimed bodies: reasons against continued dependence on an ethically dubious practice. Clinical Anatomy, 2012, vol. 25, n. 2, p. 246-254.

JONES, DG. and WHITAKER, MI. Engaging with plastination and the body worlds phenomenon: a cultural and intellectual challenge for anatomists. Clinical Anatomy, 2009, vol. 22, n. 6, p. 770-776.

JONES, DG. Re-inventing anatomy: the impact of plastination on how we see the human body. Clinical Anatomy, 2002, vol. 15, n. 6, p. 436-440.

KAGAN, II. Traditions and peculiarities of clinical anatomy education in Russia. Clinical Anatomy, 2002, vol. 15, n. 2, p. 152-156.

KEMP, M. Style and non-style in anatomical illustration: from renaissance humanism to Henry Gray. Journal of Anatomy, 2010, vol. 216, n. 2, p. 192-208.

KORF, HW., WICHT, H., SNIPES, RL., TIMMERMANS, JP., PAULSEN, F., RUNE, G. and BAUMGART-VOGT, E. The dissection course: necessary and indispensable for teaching anatomy to medical students. Annals of anatomy = Anatomischer Anzeiger: Official Organ of the Anatomische Gesellschaft, 2008, vol. 190, n. 1, p. 16-22.

LANTERMANN, ED. Der eigene Körper im spiegel der anatomie (the own body in the mirror of anatomy). In WETZ, F. and TAG, B. (Eds.). Schöne neue Körperwelten (Nice new Body Worlds). Stuttgart: Klett-Cotta, 2001. p. 279-300.

LATORRE, RM., GARCÍA-SANZ, MP., MORENO, M., HERNÁNDEZ, F., GIL, F., LÓPEZ, O., AYALA, MD., RAMÍREZ, G., VÁZQUEZ, JM., ARENCIBIA, A. and HENRY, RW. How useful is plastination in learning anatomy? Journal of Veterinary Medical Education, 2007, vol. 34, n. 2, p. 172-176.

LE FLOCH-PRIGENT, P. The Vitruvian Man: an anatomical drawing for proportions by Leonardo Da Vinci. Morphologie, 2008, vol. 92, n. 299 , p. 204-209.

LEIBERICH, P., LOEW, T., TRITT, K., LAHMANN, C. and NICKEL, M. Body worlds exhibition: visitor attitudes and emotions. Annals of Anatomy - Anatomischer Anzeiger, 2006, vol. 188, n. 6, p. 567-573.

LEMPP, HK. Perceptions of dissection by students in one medical school: beyond learning about anatomy. A qualitative study. Medical Education, 2005, vol. 39, n. 3, p. 318-325.

LIARD, RA. and LATARJET, M. Anatomia humana. 2nd ed. Sao Paulo: Panamericana, 1996.

LOUKAS, M., HANNA, M., ALSAIEGH, N., SHOJA, MM. and TUBBS, RS. Clinical anatomy as practiced by ancient Egyptians. Clinical Anatomy, 2011, vol. 24, n. 4, p. 409-415.

LOUKAS, M., LANTERI, A., FERRAUIOLA, J., TUBBS, RS., MAHARAJA, G., SHOJA, MM., YADAV, A., RAO, VC. Anatomy in ancient India: a focus on the Susruta Samhita. Journal of Anatomy, 2010, vol. 217, n. 6, p. 646-650.
MARKS JUNIOR, SC. The role of three-dimensional information in health care and medical education: the implications for anatomy and dissection. Clinical Anatomy, 2000, vol. 13, n. 6, p. 448-52.

MARKS, DL., CHANEY, EJ. and BOPPART, SA. Plastinated tissue samples as three-dimensional models for optical instrument characterization. Opt Express, 2008, vol. 16, n. 20, p. 16272-16283.

MCHANWELL, S., BRENNER, E., CHIRCULESCU, ARM., DRUKKER, J., VAN MAMEREN, H., MAZZOTTI, G., PAIS, D., PAULSEN, F., PLAISANT, O., CAILLAUD, MM., LAFORET, E., RIEDERE, BM., SANUDO, JR., BUENO-LOPEZ, JL., DONATEOLIVER, F., SPRUMONT, P., TEOFILOVSKI-PARAPID, G. and MOXHAM, BJ. The legal and ethical framework governing body donation in Europe: a review of current practice and recommendations for good practice. European Journal of Anatomy, 2008, vol. 12, p. 1-24.

MCLACHLAN, JC., BLIGH, J., BRADLEY, P. and SEARLE, J. Teaching anatomy without cadavers. Medical Education, 2004, vol. 38, n. 4 , p. $418-424$.

MELO, EN. and PINHEIRO, JT. Procedimentos legais e protocolos para utilização de cadáveres no ensino de anatomia em pernambuco. Revista Brasileira de Educação Médica, 2010, vol. 34, n. 2, p. 315332. http://dx.doi.org/10.1590/S0100-55022010000200018.

MITCHELL, PD., BOSTON, C., CHAMBERLAIN, AT., CHAPLIN, S., CHAUHAN, V., EVANS, J., FOWLER, L., POWERS, N., WALKER, D., WEBB, H. and WITKIN, A. The study of anatomy in England from 1700 to the early 20th century. Journal of Anatomy, 2011, vol. 219, n. 2, p. 91-99.

MOORE, CM. and BROWN, CM. Gunther von hagens and body worlds part 2: the anatomist as priest and prophet. Anatomical record. Part B, New Anatomist, 2004, vol. 277, n. 1, p. 14-20.

MOORE, NA. To dissect or not to dissect? American Association of Anatomists, 1998, vol. 253, n. 1, p. 8-9.

NAGER, F. The mythology of the heart. Basel: Editiones Roche, 1993.

NASH, LG., PHILLIPS, MN., NICHOLSON, H., BARNETT, R. and ZHANG, M. Skin ligaments: regional distribution and variation in morphology. Clinical Anatomy, 2004, vol. 17, n. 4, p. 287-293.

NETTERSTROM, I. and KAYSER, L. Learning to be a doctor while learning anatomy! Anatomical Sciences Education, 2008, vol. 1, n. 4, p. 154-158.

O'SULLIVAN, E. and MITCHELL, BS. Plastination for gross anatomy teaching using low cost equipment. Surgical and Radiologic Anatomy: SRA, 1995, vol. 17, n. 3, p. 277-281.

OLRY, R. Body snatchers: the hidden side of the history of anatomy. Journal of Plastination - The International Society For Plastination, 1999, vol. 14, p. 6-9.

OLRY, R. Medieval neuroanatomy: the text of Mondino dei Luzzi and the plates of Guido da Vigevano. Journal of the History of the Neurosciences, 1997, vol. 6, n. 2, p. 113-123.

PARKER, LM. Anatomical dissection: why are we cutting it out? Dissection in undergraduate teaching. ANZ Journal of Surgery, 2002, vol. 72 , n. 12, p. 910-912.

PAYNE, L. "With much nausea, loathing, and foetor": William Harvey, dissection, and dispassion in early modern medicine. Vesalius, 2002, vol. 8 , n. 2, p. 45-52.

PERSUAD, TVN. A history of anatomy: the post-pesalian era. Springfield: Charles C. Thomas, 1997.

PETAROS, A., CUlinA, T., SURAN, A. and SKrobONJA, A. Anatomical knowledge among medieval folk artists: osteological interpretation of two Dance of Death motifs. Journal of Anatomy, 2013, vol. 223, n. 2, p. 105-111. 
PRATES, PR. Símbolo do coração. Historia, Ciencias, Saude-Manguinhos, 2005 , vol. 12, n. 3, p. 1025-1031. http://dx.doi.org/10.1590/ S0104-59702005000300020.

REIDENBERG, JS. and LAITMAN, JT. The new face of gross anatomy. The Anatomical Record, 2002, vol. 269, n. 2, p. 81-88.

RIEDERER, BM. Plastination and its importance in teaching anatomy. Critical points for long-term preservation of human tissue. Journal of anatomy, 2013, vol. 224, n. 3, p. 309-315.

SEHIRLI, US., SAKA, E. and SARIKAYA, O. Attitudes of Turkish anatomists toward cadaver donation. Clinical Anatomy, 2004, vol. 17, n. 8 , p. 677-681.

SHOJA, MM. and TUBBS, RS. The history of anatomy in Persia. Journal of anatomy, 2007, vol. 210, n. 4, p. 359-378.

SHULTZ, SM. Body snatching: the robbing of graves for the education of physicians in early nineteenth century america. North Carolina: McFarland \& Company, 1992.

SLOTNICK, HB. and HILTON, SR. Proto-professionalism and the dissecting laboratory. Clinical Anatomy, 2006, vol. 19, n. 5, p. 429-436.

SORA, MC. and GENSER-STROBL, B. The sectional anatomy of the carpal tunnel and its related neurovascular structures studied by using plastination. European Journal of Neurology : the Official Journal of the European Federation of Neurological Societies, 2005, vol. 12 , n. 5 , p. $380-384$.

SORA, MC., GENSER-STROBL, B., RADU, J. AND LOZANOFF, $\mathrm{S}$. Three-dimensional reconstruction of the ankle by means of ultrathin slice plastination. Clinical Anatomy, 2007, vol. 20, n. 2, p. 196-200.

SUGAND, K., ABRAHAMS, P. and KHURANA, A. The anatomy of anatomy: a review for its modernization. Anatomical Sciences Education, 2010, vol. 3, n. 2, p. 83-93.

TUBBS, RS. and LOUKAS, M. Hic locus est Ubi Mortui Viveuntes Docent. Clinical Anatomy, 2009, vol. 22, n. 8, p. 942.
TUBBS, RS., LOUKAS, M., KATO, D., ARDALAN, MR., SHOJA, MM. and COHEN GADOL, AA. The evolution of the study of anatomy in Japan. Clinical Anatomy, 2009, vol. 22, n. 4, p. 425-435.

VESALIUS, A. De humani corporis fabrica libri septem. Basel: J Oporini, 1543.

VITRUVIUS. On architecture. In MORGAN, MH. Ten books on architecture. London: Harvard University Press, 1914. p. 69-75.

VON HAGENS, G. and WHALLEY, A. The original exhibition of real human bodies. Heidelberg: Arts \& Sciences, 2009. p. 11-41.

VON HAGENS, G. Impregnation of soft biological specimens with thermosetting resins and elastomers. The Anatomical Record, 1979, vol. 194, n. 2 , p. 247-255.

WARNER, JH. and RIZZOLO, LJ. Anatomical instruction and training for professionalism from the 19th to the 21st centuries. Clinical Anatomy, 2006, vol. 19, n. 5, p. 403-414.

WIJBENGA, BS., KONING, RH., KOOISTRA-AKSE, BJ., BOLT, S., KUKS, JB., VAN ZANTEN-TIMMER, G., VEENING, JG. and GERRITS, PO. 'Last-minute' donations influence actuarial prediction in an anatomical body donation program. Annals of Anatomy = Anatomischer Anzeiger: Official Organ of the Anatomische Gesellschaft, 2010, vol. 192, n. 1, p. 2-6.

WOLPERT, L. Development of the asymmetric human. European Review, 2005, vol. 13, supplement 2, p. 97-103.

ZAIDI, ZF. Body asymmetries: incidence, etiology and clinical implications. Australian Journal of Basic and Applied Sciences, 2011, vol. 5, n. 9, p. 2157-2191. 